Durch die Einführung von Alkylgruppen am Vierring steigt die - am Abfall der Carbonyl-Valenzschwingungsfrequenzen erkennbare - Elektronendichte am Eisen-Atom an. Der starke Abfall der Beständigkeiten der Cyclobutadien-eisentricarbonyl-Komplexe mit steigender Alkylsubstitution am Vierring ${ }^{1-4}$ ist offenbar eine Folge der oben nachgewiesenen elektro- nen-spendenden Wirkung der Alkylgruppen. Sterische Einflüsse auf die Beständigkeit sind - wie die Carbonyl-Schwingungsfrequenzen zeigen - sicher nur (wenn überhaupt vorhanden) von untergeordneter Bedeutung.

Der Deutschen Forschungsgemeinschaft und dem Verband der Chemischen Industrie danken wir für großzügige Unterstützung.

\section{Appearance and Disappearance of Phosphorylases in Potatoes}

\author{
K. N. Shivaram, H. Stegemann, R. SiepmanN, \\ and H. Boser
}

Institut für Biochemie der Biologischen Bundesanstalt, D 33 Braunschweig

(Z. Naturforsch. 26 b, 69-70 [1971] ; eingegangen am 11. November 1970)

Phosphorylase ( $\alpha$-1,4-glucan: orthophosphate glucosyltransferase, EC 2.4.1.1.) exist as different types in plant tissues ${ }^{1-6}$. We have observed up to six "isoenzymes" in different tissues of the potato plant, beans, corns and wheat ${ }^{7}$ by using our primer-technique after electrophoresis in polyacrylamide ${ }^{8}$. Especially interesting is the vanishing of one phosphorylase in potato tuber during sprouting and the concomitant appearance of a phosphorylase faster migrating in gel electrophoresis ${ }^{4}$. Changes in the amount of phosphorylase and other enzymes in connection with cell and organ de. velopment and with season have be shown to occur in plants ${ }^{9}, 10$.

However, interconversion of phosphorylases has not been reported yet nor a synthesis linked with degradation of a corresponding enzyme.

The direct relationship between a metabolic state and a) two (or three) interconvertible forms of one enzyme or b) synthesis linked with the degradation of enzymes is shown including the change brought about by slow freezing and storage at different temperature.

In a dorming tuber (variety ROSA) we observe mainly the slower of the two phosphorylases (Fig. 1 at the left). As sprouting proceeds this enzyme disappears and the faster component appears. The slow enzyme is seen within $10-15$ days after the incubation of intact tubers in glucose and phosphate or a mixture of the two with citric acid. The opposite is true, if the tuber is kept at least for 45 days in distilled water. Addition

Sonderdruckanforderungen an Dr. H. StegemanN, Biologische Bundesanstalt für Land- und Forstwirtschaft, Institut f. Biochemie, D-3300 Braunschweig, Messeweg 11/13.

1 C. Y. Tsai and O. E. Nelson, Plant Physiol. 43, 103 [1968] ; 44, 159 [1969].

2 H. StegemanN, Z. analyt. Chem. 243, 573 [1968].

3 R. Aimi and T. Murakami, Kagaku [Science] 24, 632 [1954], cited in C. A. 49, 6337e [1955].

4 H. Stegemann, Symposion on Biochemical Regulation in Diseased Plants, The Phytopathological Society of Japan, p. 137 (1968), Jahresberichte Biol. Bundesanstalt A, 63 [1967], and unpublished results.

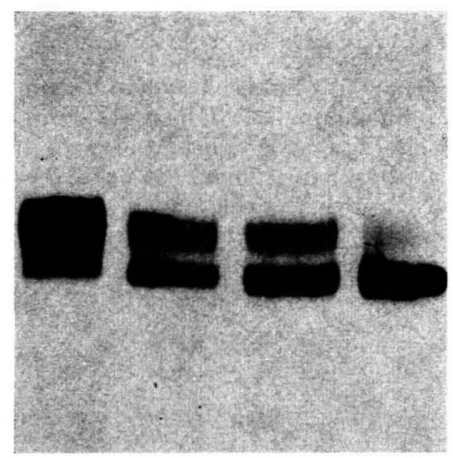

Fig. 1. Phosphorylase in sprouting tubers, variety "Rosa", from March (left) till June (right) in intervalls of 30 days. Electrophoretic conditions: $5 \%$ Cyanogum ${ }^{\circledR}$, polymerized with $0.1 \%$ glycogen in $0.25 \mathrm{~m}$ Tris-borate, $\mathrm{pH} 8.9,300 \mathrm{~V}, 125 \mathrm{~mA}$, $10^{\circ}$ for $3 \mathrm{hr}$. in a new apparatus for vertical electrophoresis (H. Stegemann, Z. analyt. Chem. 252, 165 [1970]). Sample: Freshly prepared sap from healthy tubers.

of $0,1 \mathrm{M}$ potassium fluoride or $5 \mathrm{mM}$ coffein had no effect. Identical changes take place after incubation of the respective tuber slices $(3 \mathrm{~mm})$ in a third of the time (Fig. 2).

The storage of potatoes in a coldroom $\left(-20^{\circ}\right)$ changes the gel-electrophoretic pattern of the phosphorylases. However, the changes are not uniform and are variety dependend (Fig. 3 ). - The storage at $25^{\circ}$ causes no alteration at all, whereas tubers kept at $4^{\circ}$ for 20 days or for 10 days each at $4^{\circ}$ followed by $25^{\circ}$ yield one (or two, depending on the variety) of the faster zones additional to the already existing slow one.

FREDRICK ${ }^{11}$ correlates enzymes in algae separated by electrophoretic methods with synthesis, breakdown and branching. De FEKETE 12 has looked into the mechanism of starch metabolism in beans, she assumes

5 J. F. Fredrick, Phytochemistry 1, 153 [1955]; 2, 413 [1956] ; 6, 1041 [1967].

6 M. A. R. DE Fekete, Planta 79, 208 [1968].

7 H. Stegemann and V. Macko, unpublished data.

8 R. Siepmann and H. Stegemann, Z. Naturforsch. 22 b, 949 [1967] ; Naturwissenschaften 54, 116 [1967].

9 R. Armi, Nippon Sakumotsu Gakkai Kiji 25, 124 [1956] cited in C. A. 54, 13275h [1960].

$10 \mathrm{~T}$. Yoshida and J. TAKahashi, Nippon Dojo Hirayoguka Zasshi 29, 341 [1958] cited in C. A. 55, 1816f [1961].

11 J. F. Fredrick, Phytochemistry 7, 931 [1968].

12 M. A. R. DE FeKete, Planta 87, 311 [1969]. 


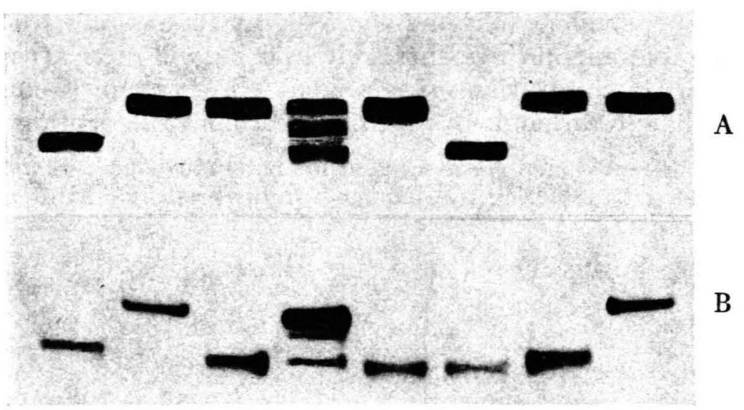

Fig. 2. Electrophoresis of phosphorylases before $(2,4,6)$ and after $(3,5,7)$ incubation. A: Glucose $2.5 \mathrm{~mm}$, same results with phosphate $17 \mathrm{~mm}$ and $33 \mathrm{~mm}$, and with the mixture of glucose $50 \mathrm{~mm}$, phosphate $200 \mathrm{~mm}$, and citric acid $10 \mathrm{~mm}$. B : Distilled water. Propylene oxide added to the incubation media as a preservative. Phosphorylases from "Rosa" $(1,6,7)$, "Lori" $(2,3,8)$ and "Ackersegen" $(4,5)$. Columns 1 and 8 are references for fast and slow enzymes.

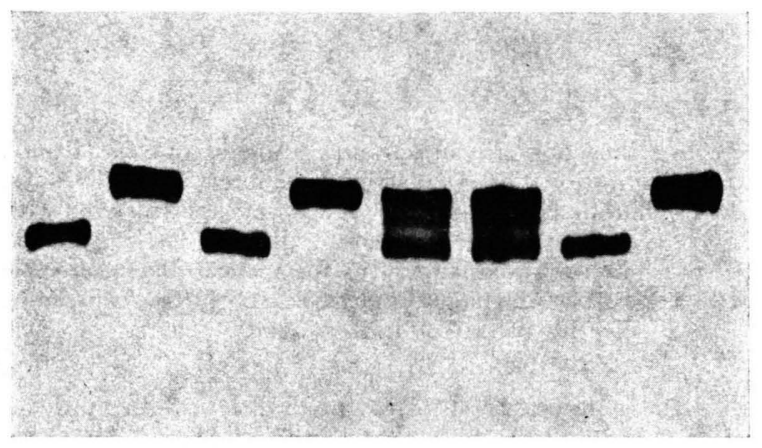

Fig. 3. Effect of freezing potatoes in a cold room $\left(-20^{\circ}\right)$. Columns 2, 4, 6 before and 3,5, 7 after freezing. Other conditions see Fig. 1, varieties see Fig. 2.

a 2-step-synthesis, first catalyzed by a transferase using ADPG or UDPG, followed by a phosphorylase using G-1-P.

13 W. Stalmans, H. De Wulf, B. Lederer, and H.-G. Hers, European J. Biochem. 15, 9 [1970].
It is also possible that two very similar enzymes play a role in a concerted action. Yet we cannot decide whether this formation of an electrophoretically slowor fast-moving enzyme can be attributed to an induction of a synthesis linked with the breakdown of a corresponding enzyme, to a conversion (for instance by splitting off or attaching a longer peptide) or to a loss or gain of a strongly charged group respectively. Because the results do not differ in the presence of potassium fluoride or caffeine, a phosphorylase-phosphatase (E.C. 3.1.3.17) should not play any role in the conversion process. The fluoride inhibits and caffeine enhances the phosphatase activity ${ }^{13}$.

We assume that the metabolic state of tubers incubated in the aforesaid incubation media are similar to the state of tubers before sprouting and soaking in water corresponds to the state after.

Unlike the changes in the incubation media the changes after freezing are not uniform and not complete in all varieties. The physical properties of the enzymes are effected by interaction with other constituents, the nature and quantity of which vary with the type of the potato ${ }^{14}$. Removal of water by freezing often leads to denaturation due to the oxidation of $\mathrm{SH}$-groups ${ }^{15}$. However, potato phosphorylase is one of the exception to this rule although it contains $\mathrm{SH}$ groups ${ }^{14}$. Sometimes one can detect an intermediate form of a phosphorylase between the fast and the slow moving enzyme, which is never seen after incubation (Fig. 2).

The electrophoretic behaviour cannot be explained by different amount of phosphate groups of the phosphorylase unless the phosphorylase-phosphatase in potatoes is not inhibited by fluoride. It shows that the enzyme in potato is quite different from the counterpart in muscle and liver, including in its metabolic properties.

We thank Mrs. U. Sunder-Plassmann and I. Müller, Miss R. KAERger and R. Fricke for their skilled assistance, the Deutsche Forschungsgemeinschaft for a grant.

14 H. Baum and G. A. Gilbert, Nature [London] 171, 983 [1953].

15 J. Levitt, Cryobiology 3, 243 [1966]. 